\title{
FAMILY MEDIATION IN ASIA: A SPECIAL REFERENCE TO THE LAW AND PRACTICE IN MALAYSIA*
}

\author{
Nora Abdul Hak ${ }^{* *}$
}

\begin{abstract}
This article seeks to discuss in general the practice of family mediation in some selected Asian countries. For this purpose the practice in Singapore, China, Japan and Hong Kong is described. However the focus of the article is the law and practice of conciliation in Malaysia which are governed by the Law Reform (Marriage and Divorce) Act, 1976. Some issues pertaining to the position of the non-Muslims in Malaysia are also highlighted.
\end{abstract}

\section{INTRODUCTION}

Mediation, being one of the oldest means of dispute resolution, has been and is regarded as the most suitable means to resolve disputes involving family matters. In China, this practice of mediation can be traced to the seventeenth century and the beginning of the Qing Dynasty where a family dispute would be settled by the head of the family, usually a

This article is a revised version of a paper presented at the $3^{\text {rd }}$ Asian Law Institute Conference, in Shanghai, China on 25-26 May 2006.

Assistant Professor, Ahmad Ibrahim Kulliyyah of Laws, International Islamic University Malaysia. 
father, grandfather or relative. In Japan, mediation has been utilized for centuries to resolve disputes. Mediation is now required before filing a suit in most family disputes. In Hong Kong, the soaring rate of divorce prompted the introduction of mediation as an alternative means, initiated by a small group of mediation trained lawyers. In Singapore, the roots of the practice of mediation can be traced back to the early $19^{\text {th }}$ century, where mediation was practised by the penghulu, immigrant forefather, clan heads and family elders. The Singapore Government has legislated for court mediation. The Woman's Charter of Singapore has been amended to include a new provision, which imposes a duty on the judge/ registrar to consider the possibility of reconciliation for the parties to a divorce or judicial separation. In Malaysia, provisions on reconciliation and conciliation have been introduced under the Law Reform (Marriage and Divorce) Act, 1976 which provides that no person shall petition for divorce unless he or she has first referred the matrimonial difficulty to a conciliatory body, and that body has certified that it has failed to reconcile the parties. Mediation (sulh) is also practised in the Syariah Court; for example, in the state of Selangor, sulh (mediation) is a prerequisite before a case is submitted for trial in court.

This article describes briefly the development and practice of family mediation in some selected Asian countries, i.e., Singapore, China, Japan and Hong Kong; and discusses the provision and practice of conciliation in Malaysia.

\section{FAMILY MEDIATION IN ASIAN COUNTRIES}

The rich traditions inmediation in Asian countries however, do not directly lead to its development as part of their socio-legal system. It is only after the development of ADR movements in the West that interest and resurgence in mediation takes place in Asia that leads to the current state of practice. Mediation in family dispute in some Asian countries is discussed below.

\section{a. Singapore}

In Singapore, mediation in the Family Court has been available since 1 March 1995. Initially mediation was provided as an alternative to 
litigation for maintenance summonses and domestic violence cases only, while divorce cases were under the jurisdiction of the High Court. In April 1996, mediation was available for divorce and ancillary matters. ${ }^{1}$ The Singapore Government has legislated for court mediation in which substantial amendments to the Women's Charter were made via the Women's Charter (Amendment) Act 1996 (the Amendments). Section 50 of the Act states "A court before which any proceeding under this Act are being heard may give consideration to the possibility of a harmonious resolution of the matter and for this purpose may, with the consent of the parties, refer the parties for mediation by such person as the parties may agree or failing such agreement, as the court may appoint." 2 Thus, mediation will not be conducted unless both parties agree to attend the mediation session.

On the above provision, Adrian Loke commented that although the provision mentions the consent of the parties, there is no safeguard to the issue of presumed or forced consent. He cautioned further on the provision, in cases where parties are unfamiliar with protocol and are uncertain over their legal rights. He added that coercion destroys an environment of frank communication, which is vital for the negotiation process. $^{3}$

Family mediation is available for two broad groups of people. First is for those who petition for a divorce and the other is for those who want relief for certain problems within the marriage. Divorce mediation is conducted prior to and subsequent to the divorce being granted. Prior to the divorce, the parties sometimes attend mediation to determine whether the petition should be contested. Subsequent to the divorce, ancillary matters such as the division of matrimonial property, maintenance for the wife and custody of the children are the issues for mediation. ${ }^{4}$

In practice, the Family Court offers free mediation service to the couples as an alternative to litigation in order to encourage the harmonious resolution of family disputes. This service is integrated into

1 Shamaine Lim, "Mediation in the Family Court of Singapore,” Research Dissertation, Faculty of Law, National University of Singapore, 1997, p. 13.

2 Singapore Women's Charter.

3 Adrian Loke, "Mediation in the Singapore Family Court," 11 S.Ac.L.J. 197.

4 Shamaine Lim, “Mediation in the Family Court of Singapore,” p. 13. 
the case process of all contested family cases, in that before hearing dates are fixed, the court will, with the consent of the parties, refer them for mediation. ${ }^{5}$

Since being introduced in 1995, mediation has proven to be very successful and gained such widespread acceptance that mediation is now the norm rather than the exception. At the Family court, most cases are settled through mediation. In Singapore, litigation is in practice used as a last resort after all attempts to settle the case amicably have failed. ${ }^{6}$ In mediation, both parties go before a mediator who will help both parties discuss and co-operate, in resolving their disputes, in a systematic and structured manner. Whatever is communicated during the mediation session is confidential. Section 50(4) of the Women's Charter states "Evidence of anything said, or of any admission made, in the course of any mediation or any counselling under this section shall not be admissible in any court."

Mediation is conducted by a deputy registrar, or by any member of the court support group, which consists of volunteers from diverse backgrounds. They comprise of sociologists, psychologists, counsellors, lawyers, pastors, teachers and court interpreters who are trained as mediators. $^{7}$

In the Syariah Court of Singapore, mandatory mediation has been introduced to allow parties to settle their disputes more amicably without being subjected to the adversarial nature of trials. It has also served the practical function of settling cases more swiftly and reducing the vast number of cases awaiting trials. Almost eighty percent of divorce cases are settled without recourse to trials. ${ }^{8}$

Mediation sessions at the Syariah Court are short, each extending to no more than half an hour. The mediator is a court officer and his role is to try to get a couple to come to an amicable settlement of the dispute. This mandatory mediation, which has been practised in the Syariah court

\footnotetext{
5 See, http://www.subcourts.gov.sg/family/programmes/mediation. Viewed on 24 March 2006.

$6 \quad$ Ibid.

7 Ibid.

$8 \quad$ Noor Aisha Bte Abdul Rahman, "The Syariah Court and the Administration of the Muslim Law on Divorce in Singapore,” $P h D$ Thesis submitted to the Department of Malay Studies, National University of Singapore, 1999, p. 2.
} 
successfully, however has not been statutorily defined in terms of its procedures and powers of the mediator. There has been suggestion that rules determining the powers of mediators as well as procedural safeguards regulating the process must be introduced. ${ }^{9}$

\section{b. China}

During the Qing Dynasty mediators were concerned with reconciling parties. Social conduct was structured around the five Confucian relationships; lord-man, father-son, husband-wife, olderyounger brother, and friend-friend; each of which involved a superior and an inferior member. ${ }^{10}$ In the husband-wife relationship the husband was superior, the wife inferior, and Confucian ethics stress that the wife's role was one of subordination to her husband. ${ }^{11}$ Disputes involving a husband and wife were settled in accordance with the relative status of the parties, generally by the head of the family. Sometimes an outside mediator, such as a maternal uncle, was brought in to settle certain family disputes, and at times relatives, friends, neighbours or community leaders would intervene to mediate a family quarrel. ${ }^{12}$

The Marriage Law of 1950 stated that when only one spouse sought a divorce, the couple was legally required to attend mediation by the district government. The same rule applied when the couple agreed to divorce but could not agree on the division of property..$^{13}$ However, the resolution of the dispute often resulted in forced reconciliation and as envisioned by Confucian heritage, the couple was encouraged to remain married in order to maintain the stable socialist family system. In 1980 the marriage laws were reformed, and a new Marriage Law was enacted, relaxing the requirement for divorce. If both parties consent to the divorce, a certificate of divorce may be issued fairly quickly. If one party petitions

\footnotetext{
$9 \quad$ Ibid.

10 Martha J. Bailey, "Mediation of Divorce in China,” 8-SPG Can. J.L. \& Soc'y 45, 1993.

11 Ibid.

12 Ibid.

13 Anne K. Subourne, "Motivations for mediation: an examination of the philosophies governing divorce mediation in the international context," 38 Tex. Int'l L. J., 2003, p. 383.
} 
for divorce, mediation remains a requirement, and the government's continued hope of reconciliation is pursued. If mediation fails, however, a divorce may be granted. ${ }^{14}$

Although the reformed law suggested a move toward using mediation to obtain a divorce rather than save a marriage, the last decade has shown a return to the promotion of reconciliation. The shift reflects both a reaction to the increase in the divorce rate and the desire to return to traditional values. Therefore, contemporary China's commitment to the alternative dispute resolution process incorporates a desire to keep marriage intact as well as its adherence to tradition. ${ }^{15}$

\section{c. Japan}

In Japan, mediation is required before filing suit in most family disputes. In divorce cases, spouses must participate in mediation prior to pursuing divorce. Most of mediation services are public mediations, which are operated by the government. ${ }^{16}$ Private legal mediation services are limited, as family disputes can be handled only by those authorised by the Japanese government to practise law. ${ }^{17}$ Under the family court system, clients are charged only a small fee to initiate mediation, which may take months, sometimes years to conclude. However, the clients are required to abide to a tightly structured setting such as that they are not allowed to choose even the chair in which they will sit. Under most circumstances the clients must comply with a routine of only one disputant meeting with the mediator at a time. The mediation committee is formally composed of a male mediator, a female mediator and a judge. The mediators are volunteers who need not have training in law, social welfare, or psychology. They must be above the age of forty and have good judgement and sound morals. The Supreme Court, primarily on the basis of letters of reference and an interview, appoints mediators. Mediators who are

\footnotetext{
$14 \quad$ Ibid.

15 Ibid.

16 Anne K. Subourne, "Motivations for mediation: an examination of the philosophies governing divorce mediation in the international context," 2003, p. 384.

$17 \quad$ Taimie L. Bryant, "Family Models, Family Dispute Resolution and Family Law in Japan," 14 UCLA Pac. Basin L.J 1, 1995.
} 
untrained in law, social welfare or psychology will rely heavily on their own experience or notions of appropriate resolutions to family problems, and they are encouraged to do so within a system in which they are selected, according to elements of good morals and common sense. ${ }^{18}$

Mediation continues to be a primary process for dispute resolution in divorce cases, where the success rate for settling divorces outside of court has risen to above ninety percent. ${ }^{19}$

\section{d. Hong Kong}

ADR was formally introduced in 1985 with the establishment of the Hong Kong International Arbitration Centre (HKIAC) following the government's recognition of the benefit of mediation and arbitration in resolving construction disputes. At the same time, the divorce rate had risen significantly in Hong Kong resulting in large numbers of single mothers needing social welfare, and mediation was utilised to reduce conflict among divorcing couples, thus encouraging responsible and cooperative post divorce parenting. The distress of divorcing families prompted single-parent and women's rights advocacy groups and the Hong Kong Family Association, to raise public awareness of family mediation. ${ }^{20} \mathrm{~A}$ small group of lawyers, social workers from the Hong Kong Catholic Marriage Advisory Council and the Hong Kong Family Welfare Society took the lead by getting trained as family mediators and initiating family mediation in their service agencies and private practices. ${ }^{21}$ In the early 1990s, the HKIAC organised mediation training and established training requirement, accreditation procedures, a code of practice, and a panel of accredited mediators. The government provides legal status for mediation services in matrimonial proceedings, funds the Pilot Scheme, promotes and publicises the service in the media and operates the service through the Social Welfare Department, while the

$18 \quad$ Taimie L. Bryant, "Family Models, Family Dispute Resolution and Family Law in Japan,” 14 UCLA Pac. Basin L.J 1, 1995.

19 Ibid.

20 Patricia L. Sullivan, Culture, "Divorce and Family Mediation in Hong Kong,” (2005) 43 Fam. Ct. Rev. 109.

21 Ibid 
Judiciary coordinates the service through the Mediation Coordinator's Office. $^{22}$

\section{FAMILY MEDIATION IN MALAYSIA}

Malaysia is yet to legislate family mediation for non-Muslim comparable to those of Singapore or Hong Kong (as discussed above) except for its inclusion in the provisions on mediation services of the Legal Aid Bureau. For the Syariah Court, the Syariah Courts of the State of Selangor has provided mediation (sulh) in its Syariah Civil Procedure Code Enactment and these are discussed below.

\section{a. Family Mediation by Government}

To date, only the Legal Aid Bureau provides mediation services to its clients, which include mediation for family disputes, for both Muslims and non-Muslims. This is provided for under Part VA of the Legal Aid (Amendment) Act 2003, and the Legal Aid (Mediation) Regulations 2006, which include, among others, appointment of mediators, process and procedure of mediation, and matters that can or cannot be mediated. ${ }^{23}$ There is also a code of ethics for mediators. ${ }^{24}$ This mediation unit is headed by a Director of mediation and has helped reduce the backlog of cases. It also saves time and is cost effective.

\section{b. Family Mediation by private institution}

There is no family mediation service provided by the private sector, though specific institutions establish mediation rules/bureau/centres

\footnotetext{
$22 \quad$ Ibid.

23 See, sections 29B, 29C, 29D, 29E, 31B and Third Schedule of the Legal Aid (Amendment) Act 2003; The Legal Aid (Mediation) Regulations 2006.

24 Faridah Abrahim, "Mediation the BBG Approach,” a paper presented in the Asia Pacific Conference on Contemporary Trends in Mediation and Arbitration. Kuala Lumpur, 17-18 July 2006.
} 
such as, the Kuala Lumpur Regional Centre for Arbitration (KLRCA rules for conciliation/mediation), the Association of Architects, Malaysia (PAM mediation rules), Banking and Financial Institutions (Banking Mediation Bureau), Insurance Companies (Insurance Mediation Bureau) and the Bar Council (Bar Council Mediation Panel Rules for Law Firm disputes).

In 1999, the Bar Council established the Malaysian Mediation Centre to encourage Malaysians to settle their disputes through mediation including family disputes. It is funded by the Bar Council, but those who use its services are required to pay the requisite fees for mediation. The mediators are drawn from a panel of trained and accredited lawyers, who are trained as mediators, as well as professionals from other fields. ${ }^{25}$ Under this service anyone may approach the Centre to request for mediation, and the Centre would commence the process by appointing a mediator. Parties may either attend the mediation themselves or may be represented by lawyers. Parties may bring in expert witness. The mediator cannot subsequently be called up as a witness in court proceedings. The parties are not allowed to use any information given during mediation in any subsequent legal proceeding. The process may be withdrawn at any stage by the mediator or either party if it is felt that no benefit may be derived out of it and the parties are bound by any settlement agreement signed by them. ${ }^{26}$ Currently the Centre mainly handles commercial disputes. It has plans to handle family disputes in future.

\section{c. Family Mediation (sulh) in the Syariah Court}

In the Syariah Court of Malaysia, family mediation (sulh) has been introduced in the Syariah Court of the State of Selangor. Section 87 of the Selangor Syariah Civil Procedure provides that the parties to an action are encouraged to hold sulh to settle their disputes. In this State, dispute resolution by mediation started its operation on the first of May 2002. Ten mediators were appointed to serve in nine Lower Courts and the High Court. A mediator or sulh officer is assigned to each of the

\footnotetext{
25 Syed Khalid Rashid, Alternative Dispute resolution in Malaysia, Kulliyyah of Laws, IIUM, KL, 2000.

$26 \quad$ Ibid.
} 
designated courts. In implementing the Civil Procedure Rule (Sulh) Selangor 2001, a Mediation Work Manual was organized for use by the mediators. This manual seeks to explain and standardize the procedures to be followed by the mediators in conducting the mediation. ${ }^{27}$

In the Syariah Court, mediation process can lead to settlement with just one meeting, depending on the abilities of the mediator and/or the nature of the dispute. Some mediators hold a minimum of two meetings, the first being the discussion and negotiation of the dispute, and the second being the signing of the agreement reached. This allows space for the disputants to deliberate or give further thought on the agreement reached, before signing it. If a case is complicated, then more separate and/or joint sessions may take place. ${ }^{28}$

Cases that reach settlement within a short duration are those submitted under sections 23, 45 or 47 of the Islamic Family Law (State of Selangor) Enactment 2003, where disputing parties are present in court to file their claims. If they then agree to go through mediation, the process may start the same day. If there is agreement reached, the chairperson will submit it to the judge for issuing of orders. ${ }^{29}$

For the first year of its practice (1/5/2002 till 31/5/2003) there were 1529 cases registered with 1416 cases (92\%) successfully concluded, out of which 1029 cases (67.3\%) achieved settlement by means of mediation. The other 387 cases $(25.3 \%)$ chose to go to trial by court and 113 cases (7.4\%) were postponed. Similarly, data from May 2002 extended to December 2003 showed a registration of 2555, where 1748 cases or $68 \%$ were successfully settled by means of mediation, 666 cases or $26 \%$ preferred trial by court and 141 or $6 \%$ were postponed. ${ }^{30}$

In the Federal Territory Syariah Court, Sulh Unit was set up in April 2005 and four sulh officers were appointed to assist the parties to achieve a settlement. As from April 2005 to March 2006, there were 482

\footnotetext{
27 (2003) JH, Vol. XVI Part II, 65.

28 See, Raihanah Azhari, "Sulh dalam Perundangan Islam: Kajian di Jabatan Kehakiman Syariah Selangor Darul Ehsan.” Ph.D Thesis, Department of Fiqh and Usul, University of Malaya.

$29 \quad$ Ibid.

$30 \quad$ Ibid.
} 
cases registered under the Unit and 432 were resolved successfully. ${ }^{31}$ Thus mediation seemed to have produced the result expected of it.

\section{CONCILIATION PROVISION AND PRACTICE IN MALAYSIA}

\section{a. Conciliation under the Law Reform (Marriage and Divorce) Act, 1976}

The appointment of the conciliatory body is stated under s 106(1) of the Law Reform (Marriage and Divorce) Act, 1976. The section provides that no person shall petition for divorce, except for dissolution under sections $51^{32}$ and $52,{ }^{33}$ unless he or she has first referred the matrimonial difficulty to a conciliatory body and that body has certified that it has failed to reconcile the parties. This provision requires the party who wants to file for divorce to refer the matrimonial problem to a conciliatory body before the presentation of a petition. ${ }^{34}$ The appointment of this conciliatory body, authorised under the LRA, 1976, has been criticised, as a reference to it is a waste of time and resources, since the disputing parties must have already sought help from members within the family circles before they decided on divorce. The decision to go ahead with a petition for divorce usually signals the absence of any likelihood of a reconciliation..$^{35}$

$31 \quad$ Mohd Naim Mokhtar, “Alternative Dispute Resolution (Sulh) in the Federal Territory Syariah Court of Malaysia," a paper presented at the International Family Law Conference, Kuala Lumpur, 16-17 January 2007.

32 This section concerns the dissolution of marriage on the ground of conversion to Islam.

33 Section 52 of the LRA, 1976 is a provision on dissolution of marriage by mutual consent.

See, Ahmad Awang, "Reconciliation and Family Courts," a paper presented at the Conference on Reform of the Law Reform (Marriage and Divorce) Act 1976, International Islamic University Malaysia, 1992, p. 1; Ahmad Ibrahim, Family Law in Malaysia, Malayan Law Journal, Third ed., 1997, p. 127; Mimi Kamariah, Family Law in Malaysia, Malayan Law Journal, 1999, p. 187.

35 Mimi Kamariah, Family Law in Malaysia, p. 188. 
The application of s 106 has become the central issue in the case of $C \vee A \cdot{ }^{36}$ The facts of the case were that the petitioner and the respondent had lived apart for more than 20 years. The petitioner prayed for a dissolution of the marriage. It was stated in his petition that attempts at reconciliation were made by his relatives without success. The respondent raised a preliminary objection that there was non-compliance with s 106 of the LRA, 1976 because reconciliation was unsuccessfully attempted by the petitioner's relatives and not a conciliatory body as defined by s 106(3) of the LRA, 1976. The petitioner submitted that since both parties had lived apart for over 20 years, this itself was clearly an exceptional circumstance within the meaning of proviso (vi) of s 106(1) of the LRA, 1976.

It was held that pursuant to s 106(1) of the LRA, 1976, obtaining a certificate from the conciliatory body that it has failed to reconcile the parties is a pre-requisite, subject to the provisos. Proviso (vi) of the Act suggests that the court must be satisfied of the existence of the exceptional circumstances, which make reference to a conciliatory body impracticable. Concerning this proviso, the court in its decision on the above case explained that:

"The very fact that both parties had lived apart with no contact with one another for well over 20 years is prima facie evidence that each of them is entitled to a dissolution of the marriage. Further, there were no infant children involved to motivate a desire for the continuance of the marriage.”

There is ambiguity as to the meaning of the terms 'exceptional circumstances' and 'impracticable' in subsection (1) (vi) as they are highly vague and ill-defined. ${ }^{37}$ These terms have remained as loose

\footnotetext{
$36 \quad$ [1998] 6 MLJ 222.

37 C.H. Liew suggested that the word 'impracticable' in s 106 (1) (vi) should be replaced by 'inappropriate' as the word 'inappropriate' will cover cases where one party refuses to be referred to conciliatory body. Concerning the word 'exceptional' she suggested that it should be deleted to avoid uncertainty over what is exceptional and what is not.
} 
concepts without any official clarification until the judgement in the case of $C \vee A .{ }^{38}$ The court in this case said:

"The object of construing an Act is to ascertain the intention of Parliament. The common sense meaning of impracticable to my mind is that a thing can only be done at an excessive or unreasonable cost. But how would the question of excessive costs apply to the use of the word impracticable in the context in which it is used in proviso (vi) to section 106 of the Act?....Therefore, it is clear that the word impracticable means impractical. The concise Oxford Dictionary $\left(9^{\text {th }}\right.$ ed.) defines impractical as not practicable. Impractical would therefore present a meaning connoting fruitlessness, a sense of futility and performing an act in vain or where it is not practical or workable to perform such an act." 39

The judge in the above case was satisfied with the evidence before him that it would be impractical if the petitioner were to refer to the conciliatory body and he went on to say that "such a referral would be an exercise in futility performed solely for the purpose of obtaining a rubber stamp to a certificate showing the failure of the body to effect a reconciliation." ${ }^{40}$

\section{Should conciliation be mandatory or voluntary?}

In the case of petitions for divorce based on the irretrievable breakdown of marriage, s 106 (1) makes it mandatory that all petitioners have to obtain a certificate from the conciliatory body testifying that it has failed to reconcile the parties before filing their petitions. This mandatory requirement of a reconciliation attempt by the parties takes place prior to the filing of the petition for divorce and it is conducted by

\begin{tabular}{ll}
\hline 38 & [1998] 6 MLJ 222. \\
39 & [1998] 6 MLJ, p. 230. \\
40 & Ibid.
\end{tabular}


out of court reconciliation bodies as specified under the LRA, 1976. ${ }^{41}$ Thus, reconciliation effort is mandatory in the following contested divorce cases;

1) adultery; 42

2) unreasonable behaviour; 43

3) desertion for a period of two years; ${ }^{44}$ and

4) separation for a period of two years. ${ }^{45}$

This compulsory reconciliation session(s) for couples who wish to divorce under section 53 of the LRA, 1976 has been severely criticised. Some criticisms attacked the very basis of this concept in that, reconciliation does not work in the Malaysian society when they petition for divorce, because most couples would have exhausted all avenues of reconciliation before they petition for it. ${ }^{46}$

Anantham contended that compulsory reference of matrimonial problems to a conciliatory body as required under s 106 (1) does not serve the intended purpose. According to him, very often, it is the party who wants the divorce who applies to the conciliatory body for the certificate required. Accordingly, he said, the intention behind the application is not to seek the assistance of the conciliatory body to resolve the disputes but merely to get the certificate. ${ }^{47}$ Dhillon in his letter to the

41

See, s 106 (2) of the LRA, 1976.

The LRA, 1976 s 54 (1) (a) which provides that the respondent has committed adultery and the petitioner finds it intolerable to live with the respondent.

Ibid., s 54 (1) (b) which states that the respondent has behaved in such a way that the petitioner cannot reasonably be expected to live with the respondent.

Ibid., s 54 (1) (c) which says that the respondent has deserted the petitioner for a continuous period of at least two years immediately preceding the presentation of the petition.

Ibid., s 54 (1) (d) which provides that the parties to the marriage have lived apart for a continuous period of at least two years immediately preceding the presentation of the petition.

Mimi Kamariah, Family Law in Malaysia, p. 188.

Anantham, K, "Reform of the Law Reform (Marriage and Divorce) Act, 1976," a paper presented at the Seminar on Family Law, Faculty of Law, University of Malaya, 1990. 
Law Commission felt that if the ground of the divorce is adultery it is surely difficult for the petitioner to take any steps to reconcile the marriage. ${ }^{48}$

The Bar Council in its meeting suggested that reconciliation should not be a condition precedent to the filing of a petition for divorce. It is claimed that this compulsory reference has created a situation whereby interim orders are not immediately available because one is barred from petitioning for a divorce without the conciliatory body's certificate and interim proceedings are an important part of divorce proceedings. As a result the legal practitioners have to look to other sources of law and procedure to protect the parties and children. ${ }^{49}$

The need for reconciliation under the LRA, 1976, however, is dispensed with in the case of the conversion of a spouse to Islam under s 51 of the LRA, 1976 and where the divorce is by way of mutual consent under s 52. ${ }^{50}$ This is reaffirmed by the case of Sivanesan $v$ Shymala, ${ }^{51}$ where Lee Hun Hoe C.J., delivering the judgement of the court held, inter alia, that:

"It is not necessary for the joint petitioners in an application for mutual divorce to state that their marriage has irretrievably broken down. Neither is

The Report of the Royal Commission on Non-Muslim Marriage and Divorce Laws, $15^{\text {th }}$ November 1971, p. 74; Rita Reddy also shares the same view when she said, "Where adultery is shown to be the main causes of the divorce it is not easy to reconcile the parties. It would make no sense whatsoever to attempt to make a spouse who wishes to present a petition for divorce on the grounds of that the other spouse having committed adultery and that he or she finds it impossible to live with the offending spouse thereafter to reconcile and live with the adulterous spouse. In effect this is what the reconciliatory provision is attempting to do." See Rita Reddy, "Reconciliation and Family Court," a paper presented at the Conference on the Reform of Law Reform (Marriage and Divorce) Act, 1976, International Islamic University Malaysia, 1992.

49 The Bar Council meeting, which was held in April 1982.

50 Rita Reddy, "Reconciliation and Family Court," a paper presented in the conference on the Reform of Law Reform (Marriage and Divorce) Act, 1976, International Islamic University Malaysia, 1992.

$51 \quad$ [1986]1 MLJ 400. 
there any requirement to make a statement that efforts at reconciliation have not been successful.”

\section{Appointment of the Conciliatory Body}

Section 106 (3) of the LRA, 1976 provides that a conciliatory body means:

'(a) a council set up for the purposes of reconciliation by the appropriate authority of any religion, community, clan or association; or

(b) a marriage tribunal; 52 or

(c) any other body approved as such by the Minister ${ }^{53}$ by notice in the Gazette.'

Section 106 (4) states:

"A marriage tribunal shall be set up for such specified area or district as the Minister may decide, consisting of a Chairman and not less than two nor more than four other members who shall be nominated by the Minister, or by such officer to whom the Minister may have delegated his powers to in that behalf."

Section 2 (1) states that Minister means the Minister charged with responsibility for the registration of marriages. Up to present, no conciliatory body has been set up under subsection (3) (c) of the LRA, $1976 .{ }^{54}$ In the case of subsection (3) (a) each of the Assistant Registrar of Marriages appointed for a church, temple or association is required to

\footnotetext{
$52 \quad$ The Marriage Tribunal is under the National Registration Department hence; the Minister in charged is the Minister of the Home Affairs.

$53 \quad$ The Minister is defined in s 2 as the Minister charged with responsibility for the registration of marriages, determines the specific areas or districts for which marriage tribunals shall be set up.

54 Ahmad Awang, "Reconciliation and Family Courts," p. 2.
} 
set up a conciliatory body comprising of members of the organisation, which he represents. For subsection 3 (b) a "marriage tribunal" is established in each district where a Registrar of Marriages, who is an officer of the National Registration Department, is located. The existence of a conciliatory body and a marriage tribunal makes it appear that there is a two-tier system, but in fact a marriage tribunal is a conciliatory body, and every such body has the same function. The only difference is that a marriage tribunal is functioning within the National Registration Department. ${ }^{55}$

Membership of a marriage tribunal is prescribed under s 106 (4) as consisting a chairman and not less than two nor more than four other members nominated by the minister or by such officer to whom the Minister may have delegated his powers. The Registrar of Marriages of the district or division is normally appointed as the chairman. Others members are appointed from members of the public on the recommendation of the State Governments, and also from government officials, particularly social welfare officers. As observed from the practice of the Marriage Tribunal of the Head Office at present, officers of the NRD (National Registration Department) are appointed to conduct the session with the Assistant Registrar acting as chairman. According to Ahmad, in some areas the District Officers sit in that capacity. ${ }^{56}$

The composition of the conciliatory bodies for the various churches, temples and associations is not prescribed, but administratively it is fixed to comprise a chairman, who is the Assistant Registrar of Marriages and four other members nominated by their organisations. These bodies are appointed on voluntary basis and members are not paid a remuneration for their services. ${ }^{57}$

There have been criticisms on the set-up of the conciliatory bodies, which were created by the LRA, 1976 to reconcile the two parties. The members of such bodies were always changing hence, the couple who appeared before them would have to repeat their marital woes when

\footnotetext{
$55 \quad$ Ibid.

$56 \quad$ Ibid.

57 Noor Farida, "Reform of Law Reform (Marriage and Divorce) Act, 1976," [1984] 1 CLJ, pp. 138-139; Zaleha Kamaruddin, Introduction to Divorce Laws in Malaysia, International Islamic University Malaysia, 1998, p. 135; Ahmad Awang, “Reconciliation and Family Courts,” p. 3.
} 
new members appeared..$^{58}$ However, it is observed that currently the members of the conciliatory bodies particularly the Marriage Tribunal consist of permanent officers of the NRD. They have stopped inviting outside officers, such as officers of the Welfare Department and counsellors to be in the reconciliation session. Thus, this resolved, the issue of constant changing of the composition of the conciliatory bodies.

\section{Qualification of the Conciliatory Body}

The LRA, 1976 does not state the qualification required of the members of the conciliatory bodies. It only provides that all members shall be nominated by the Minister, or by such officer to whom the Minister may have delegated his powers to in that behalf. ${ }^{59}$ Although it is recognised that the task of reconciling the disputes between the estranged couples should be undertaken by trained and experienced persons as it involves counselling, skill, patience and knowledge, in practice most of the members of the conciliatory bodies are composed of laymen. ${ }^{60}$ They are not equipped with proper training and experience in this noble role of reconciliation, neither are there any guidelines as to how to approach their task.$^{61}$ Rita Reddy, on this issue, suggested that there should be a proper full time appointment of a team of specialists trained in marriage counselling to be in the conciliatory bodies. She said, "the team may include a clinical psychologist and a social worker; and should be attached to and become permanent employees of the family division of the high court; and be available at all times to assist the judge of the family division at all material times as well as carry on the reconciliatory functions at other times." ${ }^{62}$ It is a fact that without the necessary training and experience in handling marital problems these members are not effective counsellors. ${ }^{63}$ R. Bhupalan in his paper remarks that:

\footnotetext{
58 Noor Farida, "Reform of Law Reform (Marriage and Divorce) Act, 1976," [1984] 1 CLJ, pp. 138-139.

59 The LRA, 1976, s. 106 (4).

$60 \quad$ Ahmad Awang, "Reconciliation and Family Courts,” p. 9; Noor Farida, "Reform of Law Reform (Marriage and Divorce) Act, 1976,” p. 138.

61 Ibid., p. 9.

62 Rita Reddy, “Reconciliation and Family Court,” p. 21.

63 Mimi Kamariah, Family Law in Malaysia, p. 188.
} 
"In connection with the appointment of persons to serve on such reconciliatory bodies it is very strongly felt that in order to be able to adequately perform their functions and fulfil their roles such persons would have to be very conversant with, fully aware of, and thoroughly familiar with, the customs, the practices, the cultural background, the religious tenets, and the economic problems confronting persons of stations in life similar to those of the parties, and these pre-requisites must be fully satisfied and established before persons are appointed to the reconciliatory bodies, if the attempts of such persons or bodies aimed at effecting a reconciliation between the parties are not to culminate merely as an exercise in futility." ${ }^{\prime 4}$

Mimi pointed out the complaint against the conciliatory body in that "the members of the body are invariably strangers, some are judgmental whilst others are prejudiced, biased or hostile." ${ }^{65}$ As a consequence, she said, "The parties are normally inhibitive and hesitant in disclosing the private details of their marriage difficulties before strangers." ${ }^{66}$ Rita, who agreed with Mimi, stressed that chances of reconciliation is more possible, if it is attempted by family members and friends of the parties. She observed that advice and persuasion by known persons has more persuasive value than total strangers. ${ }^{67}$ Hence, there should be a detailed provision concerning the qualification of the members and also guidelines as to how to carry out the reconciliation and conciliation processes.

\section{Duration of the reconciliation process}

Section 106 (5) (a) states:

64 R. Bhupalan, "Reform of the Law Reform (Marriage And Divorce) Act," a paper presented at the $7^{\text {th }}$ Malaysian Law Conference, Kuala Lumpur: October 31 to November 2, 1983, p. 3.

65 Mimi Kamariah, Family Law in Malaysia, p. 188

66 Ibid.

67 Rita Reddy, “Reconciliation and Family Court,” p. 17. 


\section{"A conciliatory body to which a matrimonial difficulty has been referred shall resolve it within the period of six months from the date of reference; and shall require the attendance of the parties and shall give each of them an opportunity of being heard and may hear such other persons and make such inquiries as it may think fit and may, if it considers it necessary, adjourn its proceedings from time to time.”}

Thus, according to this section a conciliatory body to which a matrimonial difficulty has been referred to, shall resolve it within the period of 6 months. Although an attempt at reconciliation must be done within this 6 months period, the provision allows if it considers necessary to adjourn the proceedings from time to time. There has been suggestion that the above subsection should be amended and to include a discretionary clause under it. This is to allow the members of conciliatory bodies to use their discretion in individual cases. It is proposed that once it has been determined that there is no possibility of reconciliation between the parties the certificate should be issued at the earliest possible date. ${ }^{68}$

Regarding the time frame of six months, the Federation of Women Lawyers suggested a fixed three-month period for attempts at reconciliation. ${ }^{69}$ According to Ahmad Awang the main objection to the present marriage tribunal is that they delay the process for the party to get a divorce. However, in practice he said, "The delay, if any, cannot exceed a period of six months. He then said, "It is difficult to see the reason for anyone not able to wait a few more months for a divorce

This is one of the suggestions proposed by Mary Nesarajam in her research paper. On this subsection Mary suggested that it should be repealed as she said "if the 6 month period is retained, this would indicate that the law is insensitive to the realities of the situation. In certain cases where the marriage is devoid of meaning all it needs is a decent burial. Once it has been determined that the marriage is bankrupt the certificate should be issued at the earliest possible date." See, Mary Nesarajam, "Conciliatory Bodies in Klang and Petaling Jaya," Academic Exercise, Faculty of Law, University of Malaya, Kuala Lumpur, 1983.

69 Report of the Royal Commission on Non-Muslim Marriage and Divorce Laws, p. 219. 
unless the petitioner is desperately wanting to get rid of his/her spouse in order to marry someone else and in fact the delay is a way of cooling down the heat of the matrimonial difficulty." 70

\section{The function and role of the conciliatory bodies}

The main function of the conciliatory bodies is to reconcile matrimonial disputes of the parties with the aim that they will resume the cohabitation. However, subsection (5) (b) of s 106 provides:

"If the conciliatory body is unable to resolve the matrimonial difficulty to the satisfaction of the parties and to persuade them to resume married life together, it shall issue a certificate to that effect and may append to its certificate such recommendations as it thinks fit regarding maintenance, division of matrimonial property and the custody of the minor children, if any, of the marriage.”

This subsection confers power on the conciliatory body to make recommendations in matters of division of property, custody and maintenance if it thinks necessary to do so. Although, as Mary ${ }^{71}$ pointed out that members of the conciliatory bodies are advised not to deal with recommendation regarding property, maintenance and custody of children (as the administrator feels that the court is the only competent body to deal with these matters) in practice, the members of the conciliatory bodies do make such recommendation. ${ }^{72}$ Liew who shared the same view said, "As members of the Conciliatory bodies consist of ordinary persons who volunteer to sit on the panel, it seems inconceivable from

\footnotetext{
$70 \quad$ Ahmad Awang, "Reconciliation and Family Courts,” p. 15.

71 Mary Nesarajam, "Conciliatory Bodies in Klang and Petaling Jaya," 1983.

72 Interview with Kanamah, a chairman of the Marriage Tribunal at the Head Office. Ahmad Awang in "Reconciliation and Family Courts," p. 15 however, stated "invariably in all cases no attempt is made to make such recommendations, as he said the members are lay persons who prefer such important matters to be handled by the courts."
} 
the legal point of view that volunteer laymen should be granted such wide legal powers which should be rightly accorded to the court only." 73 Thus, The Bar Council has recommended that the conciliatory body's power of recommendations regarding maintenance, division of matrimonial property and the custody of children should be deleted. ${ }^{74}$ This suggestion received support from lawyers and academicians. For example Noor Faridah argued that "as ancillary matters are vital issues in any divorce proceedings they should be resolved only after all relevant facts have been disclosed to the court under oath." "5 She went on to say "although it is agreed that it is purely in the discretion of the members to make such recommendation, if they are made under 'the circumstances mentioned, ${ }^{, 76}$ they must be seriously questioned." 77

However, it has been argued that taking away such power from the conciliatory body would restrict the scope and meaning of reconciliation. Reconciliation does not only mean reuniting partners or preventing separation. ${ }^{78}$ Reconciliation also means that it reconciles individuals to the necessity of divorce and their lonely future. Furthermore, the divorce court is not the most congenial place to 'bargain' for children and property, a less adversarial surrounding like a conciliation body might be able to achieve a better result. It is submitted also that the recommendations of the Marriage Tribunal are, as the name suggests merely recommendations. It is at the judge's discretion that he may either adopt them with or without modification or choose to ignore them

73 See also, C. H. Liew, "Reform of the Law Reform (Marriage and Divorce) Act, 1976," a paper presented at the Seventh Malaysian Law Conference, Kuala Lumpur: October 31 to November 2, 1983.

$74 \quad$ The Bar Council Meeting in April 1982.

75 Noor Faridah, "Reform of Law Reform (Marriage and Divorce) Act, 1976," p. 137.

76 What she meant by 'the circumstances mentioned' is that the recommendations, if any, made, as to ancillary matters by the conciliatory body will only be after 3 or 4 meetings with both parties. She implied that there might be injustice in the recommendation made as it is made within a short period of time and in the absent of proper procedure.

77 Noor Faridah, "Reform of Law Reform (Marriage and Divorce) Act, 1976,” p. 137.

78 See, Mary Nesarajam, “Conciliatory Bodies in Klang and Petaling Jaya," 1983. 
altogether. In $C \vee A,{ }^{79}$ the court agreed that these conciliatory bodies could make recommendation for the preservation of the property and the welfare of children. ${ }^{80}$

\section{b. Some issues in conciliation practice}

\section{Popularity of the Conciliation Institutions}

Notwithstanding the mandatory legal requirement, these bodies/ tribunals are unpopular. This is attributed to the cultural background of the couple themselves. ${ }^{81}$ Among the non-Muslims in Malaysia, reconciliation efforts, prior to the LRA, 1976, were mainly undertaken by family elders and friends in the event of any estrangement between the parties. ${ }^{82}$ In some cases, religious institutions assumed important roles in reconciliation. However, there were no formal structures as at present. ${ }^{83}$ Mimi Kamariah said, "In Malaysia where familial ties are still fairly strong, parties whose marriages are facing difficulties would invariably seek help from members within the family circle." She further said, "Only if that fails, a party would consult a lawyer and be advised on the procedures, requirements, and implications relevant to a divorce proceeding." ${ }^{84}$

In a traditional Chinese society, couples prefer to settle their disputes amicably using a third party as mediator. They were influenced by Confucian thought, which valued moral principles and had little regard for legal measures. ${ }^{85}$ It was said that:

\footnotetext{
79

80

81

[1998] 6 MLJ 228.

Ibid.

See, Sitravelu, Mary Nesarajam, "Conciliatory Bodies in Klang and Petaling Jaya," Academic Exercise, Faculty of Law, University of Malaya, Kuala Lumpur, 1983.

Rita Reddy, Reconciliation and Family Court, p. 4; see also, Goh Bee Chen, "The Traditional Chinese Concept of Law, Justice and Dispute Settlement,” Academic Exercise, Faculty of Law, University of Malaya, Kuala Lumpur, 1983.

Rita Reddy, “Reconciliation and Family Court,” pp. 4-5.

Mimi Kamariah, Family Law in Malaysia, p. 188.

Goh Bee Chen, op. cit., p. 204; see also James A Wall et al., "Malaysian Community Mediation,” Journal of Conflict Resolution, Beverly Hill, 1999.
} 


\begin{abstract}
"Culturally the common law justice system runs counter to the rural Chinese Malaysian beliefs. The English judicial process requires of a judge a verdict rather than a compromise solution. This necessarily excludes the Confucian concept of yielding and compromise...." 86
\end{abstract}

Goh Bee Chen found that it is a shame for a Chinese family if the couple takes their marital problems to court for settlement. Most Chinese families adhere to the concept of "kang-ching" (good relationship), thus they will try their best to resolve the problem among themselves within the family without seeking outside assistance. ${ }^{87}$ Newman, ${ }^{88}$ discussing the emergence of ADR in his book, stated that, Donahey in his writing 'Seeking Harmony' ${ }^{89}$ has identified the Chinese approach of preferring mediation to adjudication as being in keeping with traditional Confucianism. He also found out that a similar situation exists under other Asian legal systems, including the Korean..$^{90}$

As for the Indians in Malaysia, before the enactment of the LRA, 1976 there were no specific rules governing the grounds and forms of Hindu customary divorce. They practised their own religious usages and rites, which originated from homeland India. ${ }^{91}$ Like the Chinese, Indians too prefer to settle the disputes without going to court. ${ }^{92}$ The Indian couple who is in dispute normally approaches the elders in the family or in the community such as the local religious head or community leader for the settlement of their dispute..$^{93}$ Thus, they prefer the assistance of an informal third party to resolve their intra-familial problems.

\footnotetext{
$86 \quad$ Ibid.

$87 \quad$ Ibid

$88 \quad$ Newman, Paul, Alternative Dispute Resolution, CLT Professional Publishing Ltd, 1999, p. 27.

$89 \quad$ [1995] 61JCI Arb 4, p. 279.

$90 \quad$ See, James A Wall et al., 'Malaysian Community Mediation,' Journal of Conflict Resolution, Beverly Hill, 1999.

$91 \quad$ Zaleha Kamaruddin, Introduction to Divorce Laws in Malaysia, p. 78.

92 Zaleha Kamaruddin, Isu-Isu Kekeluargaan dan Undang-undang, ABIM, Kuala Lumpur, 1997, p. 194.

93 Ibid.
} 
Mary in her research pointed at the reasons for the lack of popularity of the conciliatory councils set up under s 106 (3) (a). Among the reasons is that the couple feels uncomfortable divulging their marital problems to the members of the religious groups. As the religious councils are very close-knit groups, couples feel ashamed 'to wash their dirty linen' in front of righteous and upright members of the community. She also stated that couples are cautious of the religious bodies and organisations whose members might be religious fundamentalists who will try to save the marriage at all cost. ${ }^{94}$

\section{Attendance of the parties}

The respondent usually wilfully refuses to attend the session although a notice letter has been served, and this is the general complaint of the members of the marriage tribunal. ${ }^{95}$ There is a very high incidence of non-attendance by the respondent and sometimes even the petitioner himself fails to attend the session. ${ }^{96}$ Mimi, pointed at the difficulties in securing attendance of all members of the conciliatory body on the appointed dates. As a result there have been frequent postponements of the hearings. ${ }^{97}$ This, according to Mimi, would certainly aggravate the already tense and unfortunate situation of the spouses themselves. ${ }^{98}$

Another problem in the law as regards non-attendance is that irrespective of whether the couple attends or not the chairman has to issue a certificate at the end of a six-month period, as required under the law. There is no discretion for the marriage tribunal to withhold issuing a certificate for wilful non-attendance.

\footnotetext{
94 Sitravelu, Mary Nesarajam, "Conciliatory Bodies in Klang and Petaling Jaya,” 1983.

95 A formal interview had been conducted by the author with member of the Marriage Tribunal of the Head Quarters, Petaling Jaya, Selangor, which took place in November 1999. On this issue, the officer of the Marriage Tribunal at Putra Jaya when contacted recently mentioned that they are still facing the same problem in getting the respondent to attend the session.

$96 \quad$ Ibid.

97 Mimi Kamariah, Family Law in Malaysia, p. 188.

$98 \quad$ Ibid
} 


\section{Absence of a provision for secrecy}

Unlike the law in Australia, there is no provision for secrecy of information given during the reconciliation session under the LRA, 1976. Noor Farida criticised that "although there are directives from relevant authorities as to the necessity for secrecy, beyond a reprimand there is no further sanction for this provision." 99 She felt that conciliatory bodies should draw up their own Code of Ethics and suggested an amendment in this aspect of the law. ${ }^{100}$

\section{Administrative difficulties}

It is observed that the conciliatory councils appointed under s 106 (3) (a) of the LRA, 1976 are scattered all over the Federal Territory of Kuala Lumpur and Petaling Jaya, with no central location or landmark, which makes these bodies less easily accessible to the public as compared to the marriage tribunals.

The Federation of Women Lawyers recommended that the administration of the conciliatory bodies should be removed from the National Registration Department, as they claimed their ordinary functions do not normally include such type of welfare activities. ${ }^{101}$ They suggested for the setting up of a Family Court in Malaysia and advocated that the whole system of counselling, and other welfare services, which are essential in family matters, should become part and parcel of the Family Court infrastructure. ${ }^{102}$ Awang in his paper welcomes the suggestion for the establishment of the family court, which handles all matrimonial cases including the existing function of the Marriage Tribunal. ${ }^{103}$

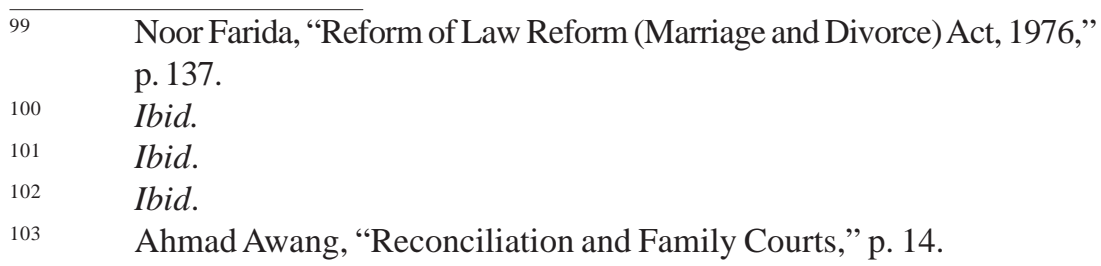




\section{CONCLUSION}

Mediation as a method in resolving family disputes is not a new phenomenon. In most oriental cultures such as China and Japan, mediation has long been used as a means for resolving disputes as it emphasises on moral persuasion and maintaining harmony in human relationship, and thus incorporated into their practice of justice since then. It will continue to be the primary means to solve disputes as evidenced by current successes in resolving disputes. In Singapore and Malaysia, the practice of mediation can be traced back to the early $19^{\text {th }}$ century, practised by the immigrant forefathers, penghulus, clan heads and family elders. In Singapore under the current Family Court, mediation service is offered free to the clients in order to encourage the harmonious resolution of family disputes. Since the introduction of mediation in the Singapore Family Court, most cases are settled through it. Litigation is therefore used as a last resort after all attempts to settle the case harmoniously have failed. In Hong Kong, the introduction of mediation as an alternative to litigation is a new approach to intervention with divorcing families, and in spite of prediction to the contrary, preliminary evidence supports its acceptability and effectiveness. Acceptability and effectiveness of mediation as an intervention may be related to the cultural beliefs of the Chinese families about failure and shame associated with marital breakdown and reluctance to seek outside help.

In Malaysia, the term 'mediation' has yet to appear in family law. The older terms conciliation and reconciliation are still in existence. The practice of conciliation (among the non-Muslims) has been confronted with many problems and weaknesses. It has been said that the overall weakness of the conciliatory bodies including the Marriage Tribunal is that it lacks direction, co-ordination and uniformity. Generally the blame is pointed at the conciliation provisions in the LRA, 1976, which are said to be insufficient to effectively reconcile the couple. Hence, very few cases of reconciliation have been successful. It is therefore proposed that the marriage tribunal in the National Registration Department be abolished and a new unit be established in the Family Division of the High Court or as suggested above, a family court be set up. This will have the responsibility of implementing the relevant provisions of the LRA, 1976; and having under its roof, the ADR mechanisms such as mediation, their management and development. The unit/court should offer mediation, counselling or other related services to married couples 
as in the Singapore Family Court where mediation and counselling form part of the overall case flow management of cases. In the context of family mediation, development should include aspects such as, information dissemination, promotion of mediation, code of practice, training, qualification, standards and interdisciplinary programs. This should lead to the practice of mediation within the environment of the court/judiciary replacing conciliation and reconciliation, and relevant laws should be enacted to improve or replace the existing ones, taking into consideration the attendant issues discussed.

Should the above proposed change materialise, Malaysia can then truly be among the league of Asian nations that have ratified mediation for family disputes. This will go a long way to 'returning to roots' as most Asians consider mediation (and sulh in Islam) to be their heritage that has been intellectualised and institutionalised by the West. Mediation, as a heritage, has helped families settle their disputes in their own specific ways, amicably, with respect for each other should they decide for divorce or separation. The stability and integrity of the family in Asia is definitely of fundamental importance as it provides the basis for the socio-economic and political development of the Asian society. 